\title{
Enumeration of sandy sediment bacteria: Are the counts quantitative or relative?
}

\author{
S. S. Epstein ${ }^{1, *}$, D. Alexander ${ }^{2}$, K. Cosman ${ }^{2}$, A. Dompé ${ }^{2}$, S. Gallagher ${ }^{2}$, J. Jarsobski ${ }^{2}$, \\ E. Laning ${ }^{2}$, R. Martinez ${ }^{2}$, G. Panasik ${ }^{2}$, C. Peluso ${ }^{2}$, R. Runde ${ }^{2}$, E. Timmer ${ }^{2}$ \\ ${ }^{1}$ Marine Science Center, Northeastern University, East Point, Nahant, Massachussetts 01908, USA \\ ${ }^{2}$ Boston University Marine Program, Marine Biological Laboratory, Woods Hole, Massachussetts 02543, USA
}

\begin{abstract}
Several tests were carned out to enable evaluation of the precision with which sandy sediment bacterla could be enumerated. This represented the first attempt to place direct epifluorescence counts of benthic bacteria on a quantitative, rather than relative, ground. The tests combined in situ radioisotope $\left[\left[{ }^{3} \mathrm{H}\right],\left[{ }^{14} \mathrm{C}\right]\right)$ labeling of sediment bacteria, bacterial dislodgment by ultrasonic treatment, and bacterial enumeration via fluorescent staining. The results provided direct and indirect evidence that the employed protocol for bacterial enumeration accounted for 88 to $98 \%$ of all bacteria present in sediments. The identified approach thus allowed for a rather complete quantification of sediment bacteria. Since this protocol was more effective that the alternative techniques used in earlier studies, sediment bacteria may have been repeatedly undercounted in the past.
\end{abstract}

KEY WORDS: Bacteria Sediment - Enumeration Epifluorescence Radioactive labeling

\section{INTRODUCTION}

Bacterial abundance is a basic parameter used to characterize aquatic microbial communities. However, counting of sediment bacteria is flawed by major difficulties. There is no single enumeration approach for which absolute efficacy is known; the available techniques all give relative rather than absolute counts. As relative measures, these techniques were extensively compared (Dale 1974, Meyer-Reil et al. 1978, Dye 1983. Ellery \& Schleyer 1984), and the most effective ones were further optimized (Velji \& Albright 1986. 1993, Schallenberg et al. 1989). Based on that, Epstein \& Rossel (1995) developed a protocol which appeared more refined, but it is still not known what proportion of the extant bacteria is actually being counted.

Among the many steps in sediment bacterial enumeration, dislodgment of attached bacteria is the most crucial one, and the efficacy of dislodgment may be an estimate of the efficacy of the overall counting procedure (Epstein \& Rossel 1995). In this paper, we

·E-mail: sepstein@lynx.dac.neu.edu designed and employed an approach to test the absolute efficacy of the bacterial dislodgment. The approach was based on a technique commonly used to measure bacterial production, that is, on bacterial in situ labeling with $\left[{ }^{3} \mathrm{H}\right]$ thymidine and $\left[{ }^{14} \mathrm{C}\right]$ leucine. Upon radioactive labeling, sediment samples were sonicated, and dislodged bacteria were washed out of the sediment. The level of radioactivity was quantified in the washes, which contained the dislodged bacteria, and in the sediments, which harbored dislodgmentresistant, particle-bound bacteria. We hypothesized that the ratio between the two would be indicative of the efficacy of the dislodgment protocol and thus of the overall efficacy of the bacterial enumeration. This represented the first attempt to evaluate the percent of bacteria being counted and thus the first assessment of the precision of sediment bacteria direct enumeration.

\section{MATERIAL AND METHODS}

Experimental site. Sediment samples were collected at 2 sites. Site A, described previously (Epstein \& Rossel 1995, Epstein 1997 a, b), was located near the 
Marine Science Center of Northeastern University $10 \mathrm{~km}$ north of Boston, Massachussetts, USA. Site B was located in Great Sippiwisset Marsh, near the Marine Biological Laboratory, Woods Hole, Massachussetts. In both cases, the samples were collected at a mid-tide level, and the sediments were microporal sands with a low mud and clay fraction.

Enumeration of sediment bacteria. The complete protocol is detailed elsewhere (Epstein \& Rossel 1995). In short, sediments samples $\left(0.4\right.$ to $\left.0.7 \mathrm{~cm}^{3}\right)$ were preserved with $2 \mathrm{ml}$ of 2 to $4 \%$ formaldehyde and sonicated for 0 (hand shaking treatment), 10, 20, 40, 80, 160 , or 320 s with a $50 \mathrm{~W}$ Ultrasonic Processor VT-50 (Sonics \& Material, Dunbery, CT) equipped with a $3 \mathrm{~mm}$ stepped probe vibrating at $320 \mu \mathrm{m}$ amplitude (setting $40 \%$ ). Treatments over 80 s were interrupted 2 to 4 times to avoid sample overheating Upon bacterial dislodgment, samples were vigorously shaken for $10 \mathrm{~s}$, and supernatants with detached bacteria were decanted. Four more washes were performed, each time with $2 \mathrm{ml}$ of fresh fixative, and all 5 washes were combined, subsampled, and stained with 4',6diamidino-2-phenylindol (DAPI 10 to $15 \mathrm{~min}$ staining

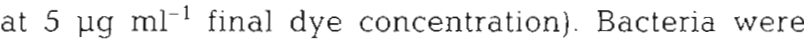
concentrated on Poretics $0.2 \mu \mathrm{m}$ pore-size polycarbonate black filters, which were then rinsed twice with particle-free water. Bacteria were counted under Zeiss Axiophot microscopes equipped for epifluorescence [50 or $100 \mathrm{~W}$ mercury lamp. DAPI filter blocks 9108460094 (365/400/450 nm excitation filter/beam splitter/barrier filter, respectively)]

Bacterial counts were conducted in 3 to 7 replicates. In some cases, microphotographs of DAPJ-stained bacteria were taken, the images were manually measured upon their projection on a screen, and the measurements were converted into bacterial biovolume.

In situ $\left[{ }^{3} \mathrm{H}\right] /\left[{ }^{14} \mathrm{C}\right]$ labeling. Sediment samples were collected with help of a rectangular $(9 \times 7 \mathrm{~cm})$ hand core to a depth of $5 \mathrm{~cm}$. From the core, samples could easily slide, with minimal disturbance, into appropriately sized glass containers $(9.5 \mathrm{~L} \times 7.5 \mathrm{~W} \times 6 \mathrm{H} \mathrm{cm})$. Sediments were kept in these containers covered with $5 \mathrm{~mm}$ of overlying water; the experiments were conducted within a few hours after field sample collection.

Radioactive tracers were administered to the sediments as described earlier (Epstein 1997a, b). Thymidine- and leucine-specific procedures were adapted, as described in the above papers, from Findlay (1993) and Kirchman (1993), respectively. In short, each sample received, via a multiple injection (19 syringes of $1 \mathrm{ml}$ each in a cassette simultaneously delivering their contents over $35 \mathrm{~mm}$ depth), $\left({ }^{3} \mathrm{H}\right.$ |thymidine and $\left[{ }^{14} \mathrm{C}\right]$ leucine $(50$ and $680 \mathrm{nM}$ final concentrations, respectively). After 30 to $35 \mathrm{~min}$ incubation, sediments were sampled down to $3 \mathrm{~cm}$ depth with $1 \mathrm{ml}$ syringes with the Luer end cut off, and preserved with $2 \%$ formaldehyde. To evaluate the abiotic label absorption, several control treatments were established. These included a 0 incubation control (samples were taken immediately upon the label delivery) and a pre-killed, 30 min incubated control. Since the nature of the fixative might influence the amplitude of abiotic label absorption, the following fixatives were separately tested: $2 \%$ formaldehyde, $5 \%$ cold trichloroacetic acid (TCA), and $96 \%$ ethanol. All experimental and control treatments were conducted in 3 to 7 replicates

In both control and experimental treatments, bacteria were dislodged either by shaking or sonication (see 'Enumeration of sediment bacteria') for $80,160,320$, or $480 \mathrm{~s}$ (each in 6 replicates). Dislodgment was followed by washing ( 5 cycles) of the dislodged bacteria, and the 5 washes were combined. Sonicated/hand washed sediments and combined washes were treated separately for the label recovery and radioassay.

The washes containing dislodged bacteria were subsampled (1 $\mathrm{ml})$, and bacteria were concentrated on nitrate cellulose $0.2 \mu \mathrm{m}$ pore-size filters. Filters were rinsed 3 times with ice-cold $5 \%$ TCA $(5 \mathrm{ml}$ for $5 \mathrm{~min}$ each time) to wash the unincorporated label. To keep the extraction temperature low, either the filtration and rinsing were performed inside a refrigerator, or the filtration assemblies with the filters in place were refrigerated for a few minutes in between washes. Filters were placed into scintillation vials, dissolved in $1 \mathrm{ml}$ of ethyl acetate, and radioassayed for both labels

The combined washes from 2 tests (Tests 3 and 4 , see 'Results') were also subsampled to enumerate, via DAPI staining, the dislodged bacteria as detailed above.

From the sediments, unincorporated label was extracted by $5 \%$ ice-cold TCA. Three washing cycles were performed, each consisting of the addition of $5 \mathrm{ml}$ of TCA, resuspension, centrifugation at $4000 \times g$ for 15 min, and decantation of the supernatant. Macromolecules were extracted overnight in an alkaline extractant $(0.3 \mathrm{~N} \mathrm{NaOH}$ in $0.1 \%$ SDS and $25 \mathrm{mM}$ EDTA) After extraction, sediments were resuspended, briefly centrifuged $(5 \mathrm{~min}$ at $1000 \times \mathrm{g}$ ), and subsamples of supernatant were radioassayed for both labels. The obtained counts were recalculated into $\mathrm{dpm}$ and corrected for quenching using $\left[{ }^{14} \mathrm{C}\right]$ and $\left[{ }^{3} \mathrm{H}\right]$ internal standards

Specificity of isotope labeling. On several occasions, the rate of isotope incorporation into the target molecules (DNA and proteins) was checked. Standard phenol/chloroform protocol (Sambrook et al. 1989), which separated (1) nucleic acid fraction from (2) proteins + cell debris fraction, was employed. This approach was chosen after initial attempts failed to achieve reproducible results via hot TCA hydrolization technique 


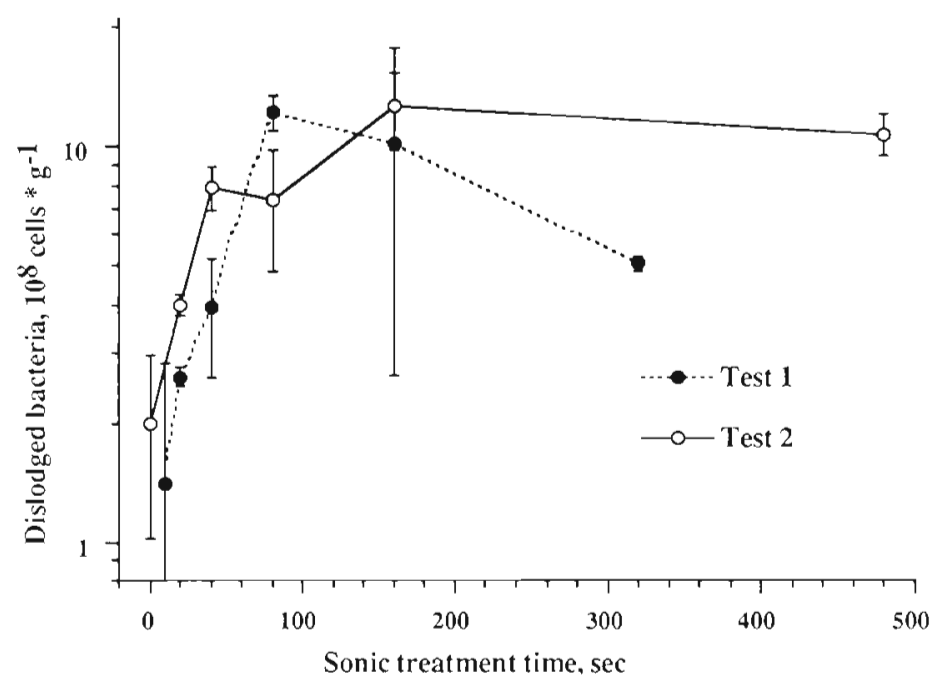

Fig. 1. Effect of different sonication regimes on the dislodgment of attached sediment bacterua. Shaded area encircles statistically indistinguishable results representing the optimal treatment. Bars show \pm SE

(Findlay 1993). The $\left[{ }^{3} \mathrm{H}\right]$ label in the first fraction was assumed to be incorporated into DNA because thymidine incorporation into RNA was unlikely during short incubations (Bell 1993 and references therein). The $\left[{ }^{14} \mathrm{C}\right]$ label in the second fraction was assumed to be in proteins because leucine was shown to incorporate almost exclusively into the target molecules (Kirchman et al. 1985) and thus would not be found in cell debris. All the relavant tests were conducted in triplicate.

Statistics. Kruskal-Wallis non-parametric test (Sokal \& Rohlf 1987) was used throughout the study.

\section{RESULTS}

\section{Test of different dislodgment protocols for enumeration of sediment bacteria}

Two tests were conducted employing sediments from the 2 sampled areas. Tests 1 and 2 (sediments from Sites $A$ and $B$, respectively) were designed similarly; these checked the effect of varying sonication regimes on the number of dislodged bacteria. In both cases, the number of bacteria dislodged from the sediment samples grew 5- to 10 -fold as the length of ultrasonic treatment increased from $0-10$ to $80-160 \mathrm{~s}$ (Fig. 1). Thereafter, the cumulative number of countable bacteria either leveled off or declined. The 2 tests showed different optimal sonication times (80 and 160 s). However, the 4 relevant counts, encircled in Fig. 1, were not statistically different ( $p>0.1)$, and it was tentatively concluded that the optimum sonication time was not represented by a single value, but rather by a time interval. Interestingly, optimal sonication times determined previously with different cell disrupters, different probes, and for different sediments belonged to the above range $[145 \mathrm{~s}$ (Epstein \& Rossel 1995) and 150 s (Starink et al. 1994)]

\section{Sonication efficacy tests}

Two independent tests, each of which employed the sediments from both sources, were conducted.

The results of Test 3 are presented in Fig. 2 . The amount of radioactivity remaining in the sediment decreased as the sonication length increased, presumably due to bacterial dislodgment, which became progressively more and more efficient. This decrease was matched by a proportional increase in the level of radioactivity of the washes, which were harboring the dislodged bacteria. The optimal sonication was $\geq 160 \mathrm{~s}$ for both labels, but the
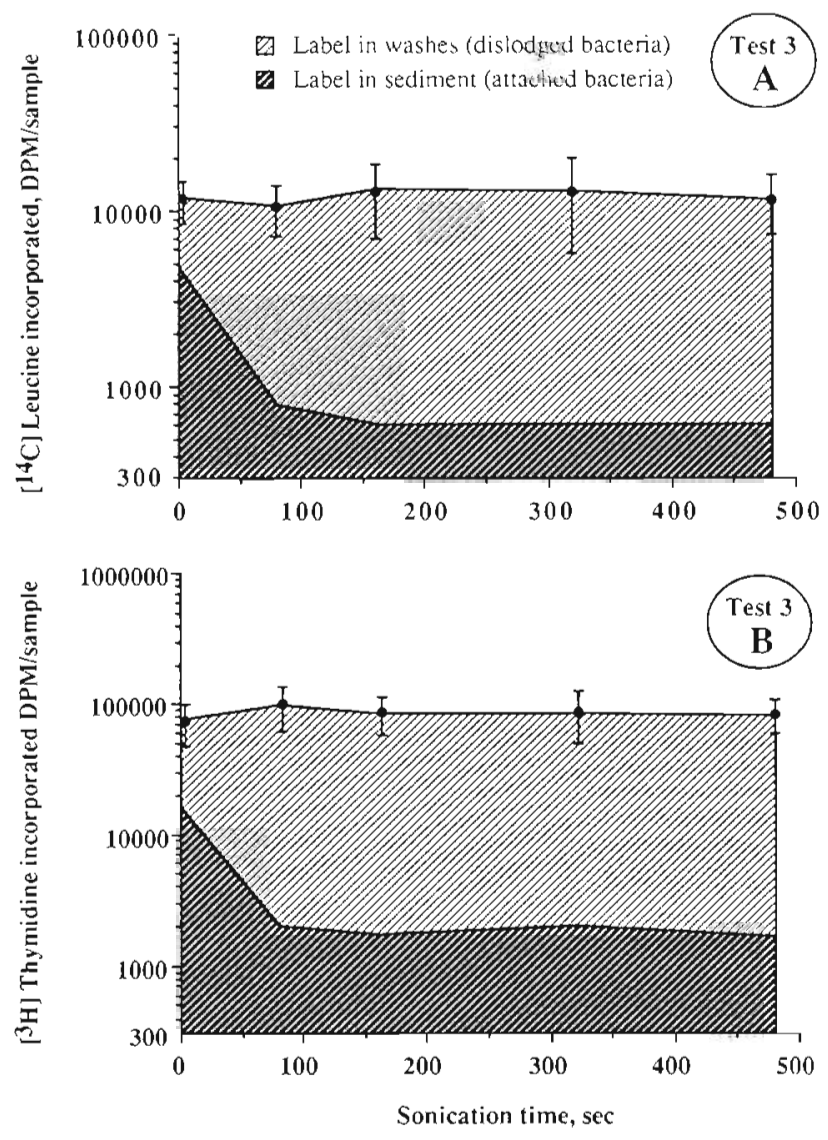

Fig. 2. Effect of different sonication regimes on the dislodgment of $\left[{ }^{3} \mathrm{H}\right]$ - and $\left.\mid{ }^{14} \mathrm{C}\right]$-labeled bacteria. Bars show $\pm \mathrm{SE}$ 


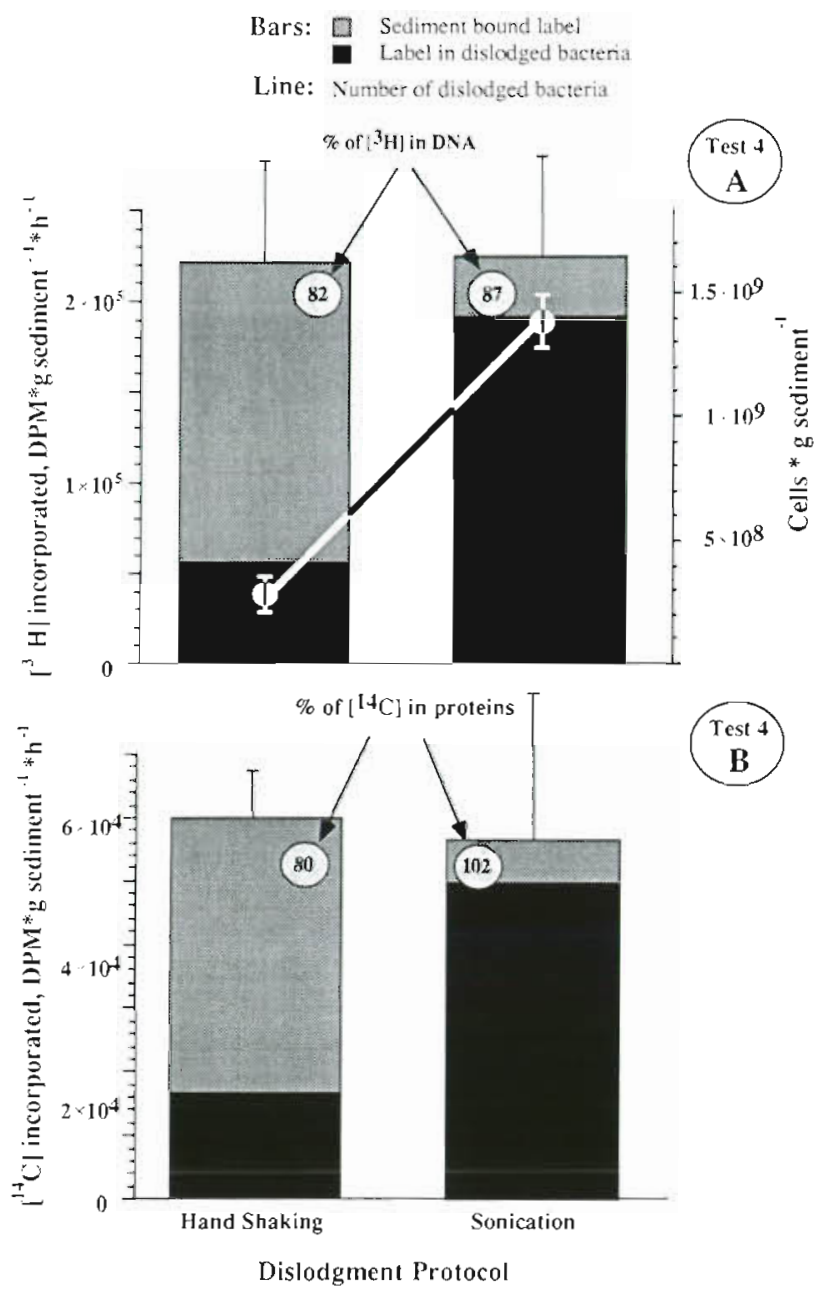

Fig. 3. Identical treatments cause identical increase in the number of dislodged bacteria (total count) and the number of detached active $\left(\left[{ }^{3} \mathrm{H}\right]\right.$ - and $\left[{ }^{14} \mathrm{C}\right]$ labeled) bacteria. Note: increase in bacterial counts is equally applicable to both plates $A$ and $B$, but is shown only once (plate $A$ ). Bars show \pm SE

achieved dislodgment was statistically indistinguishable from that at $80 \mathrm{~s}$. At longer treatments, the amount of the label in both the sediment and the washes leveled off and did not change with increased $(480 \mathrm{~s}$ maximum) sonication time. The control treatments, which employed different fixatives and different incubation times, exhibited a uniformly low level of non-specific incorporation, which was always under $10 \%$ of the corresponding experimental counts

Test 4 checked the relationship between the increase in the amount of radioactive label in the washes and the increase in the number of dislodged bacteria. The results are presented in Fig. 3. Compared to hand shaking, 80 s sonication resulted in a 3.3 -fold increase in the amount of label. in the washes and a 4.8 -fold increase in the number of dislodged bacteria. This latter increase was not due to sonication-caused cell breakage since the size distributions of bacteria dislodged by hand shaking and by 80 s sonication were identical (Fig. 4) The test also checked the specificity of the label incorporation. The latter proved to be uniformly high $(>80 \%)$ for both $\left[{ }^{3} \mathrm{H}\right](\mathrm{DNA})$ and $\left[{ }^{14} \mathrm{C}\right]$ (proteins) (Fig. 3).

\section{DISCUSSION}

The main goal of this study was to check the following hypothesis: $\left(\mathrm{H}_{0}\right)$ direct counting of sediment bacteria could provide a quantitative estimate of their abundance. Since the dislodgment of bacteria attached to sediment particles was the most uncertain step in the overall counting procedure, confirmation versus rejection of the hypothesis depended on whether or not it was possible to quantitatively dislodge sediment bacteria. Until now, the dislodging techniques have been compared to each other exclusively in their relative efficacy (Dale 1974, Meyer-Reil et al. 1978, Dye 1983, Ellery \& Schleyer 1984, Epstein \& Rossel 1995), and no technique has been qualified as suitable, or disqualified as inappropriate, in terms of absolute bacterial numbers. Two factors were responsible for that uncertainty. First, it was difficult to evaluate how complete the achieved dislodgment was. Second, even if the dislodgment was complete, as suggested by SEM observation of sonicated sediment particles (Epstein \& Rossel 1995), there was no guarantee that the dislodgment, while detaching cells, was not simultaneously destroying some of them.

The efficacy of a direct counting technique could be determined by its evaluation against an independent technique known to be $100 \%$ efficient. Since it is exactly the latter that was needed in the first place, the technique with known efficiency appeared to be a pre-

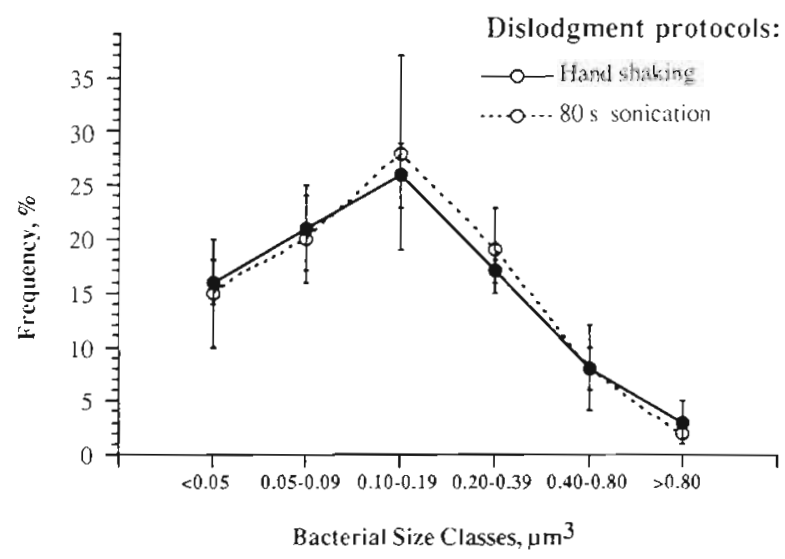

Fig. 4. Size distributions of bacteria dislodged from sediments by hand shaking vs sonication. Bars show $\pm \mathrm{SE}$ 
requisite for its own development. We suggest here an indirect solution for that apparently paradoxical situation. If, instead of bacterial absolute number, it were possible to quantitatively evaluate the proportion of bacteria remaining in the sediment after dislodgment, relative to the pre-treatment situation, the problem would be solved. With some assumptions, bacterial activity, in the form of DNA/protein synthesis, can be used for that purpose. First, bacteria were radioactively labeled in situ using $\left[{ }^{3} \mathrm{H}\right]$ thymidine and $\left[{ }^{14} \mathrm{C}\right]$ leucinebased approaches. At this stage, the experiments followed well-known protocols for bacterial production measurements. The similarity ended after the incubation was completed and the sediments were fixed. The latter were subsampled, and the subsamples were subjected to a dislodgment treatment, as if bacterial enumeration by direct counting was to follow. Sample sonication, shown earlier to be one the most effective ways to detach bacteria (Epstein \& Rossel 1995), was chosen here as the treatment of choice. Dislodgment was followed by sample washing, which physically separated the detached bacteria from sediment particles. Thereafter, the incorporated label was found in washes (dislodged bacteria) as well as in sediments (bacteria still attached to sediment particles). We assumed that the more effective the dislodgment protocol was, the more label would be found in washes $(W)$, and the less would remain in the sediment $(S)$. The value of $W /(W+S)$ would estimate the absolute efficacy of the employed dislodgment, with no need to actually count the dislodged bacteria.

There were 2 important assumptions. First, that the attachment of active (label incorporating) bacteria was identical to that of inactive bacteria. Second, that sonication caused no cell destruction/leakage. The latter assumption probably held [see (3) below]. The first assumption could be checked by analyzing phospholipid fatty acid contents (Findlay \& Dobbs 1993) of the intact sediments, sonicated sediments, and the washes. Planned for the future, PLFA analyses were not carried out in this study, but some indirect evidence [see (2) below] indicating that the first assumption was likely to hold will be described.

The obtained data provided the following arguments to support the $\mathrm{H}_{0}$ : (1) Sample sonication resulted in the dislodgment of the $\left[{ }^{3} \mathrm{H}\right]$ - and $\left[{ }^{14} \mathrm{C}\right]$-containing particles, presumably bacteria, which could be washed from the sediment and collected on $0.2 \mu \mathrm{m}$ filters (Figs. $2 \& 3$ ). (2) The number of these particles, judged by their combined radioactivity, grew proportionally with the number of bacteria observed in the washes via DAPI staining (Fig. 3). These particles were most likely active bacteria. Because their appearance in the washes was mirrored by the proportional increase in the total number of bacteria, the nature, rate, and strength of attachment seemed to be similar between active and non-active bacteria. Thus, the only bacteria that could potentially bias the results would have to satisfy simultaneously 3 requirements: to be active, to be incapable of incorporation of either leucine or thymidine, and to be able to completely resist any dislodgment treatment. In our view, this is an unlikely combination. (3) Upon dislodgment, radioactive label was found in both the sediment and washes. The sum of the 2 values did not seem to depend on how harsh the dislodgment protocol was (hand shaking vs sonication of various length; Figs. $2 \& 3$ ). Thus, sonication appeared to have destroyed a marginal, non-detectable number of bacteria. Also, the fact that the size distribution of dislodged bacteria was the same regardless of the dislodgment protocol used (hand washing vs sonication; Fig. 4) was a further indication that sonication did not break bacteria into DAPI-stainable cells' halves, quarters, etc. (4) A possibility existed that some radioactive label could be absorbed abiotically by sediment particles. If the absorbed label had resisted dislodgment and remained in the sediments after sonication, it could have been mistaken for non-dislodged bacteria. However, sediment bound radioactivity was largely contained in the target molecules $\left({ }^{3} \mathrm{H}\right]$ in DNA and $\left[{ }^{14} \mathrm{C}\right]$ in proteins; Fig. 3) before as well as after the dislodgment treatment. Therefore, the label found in the sediments after sonication was as likely to be inside bacterial cells as it was before any treatment. Low levels of radioactivity in both the fully incubated prekilled control and in the 0 incubation control (always under $10 \%$ of the corresponding experimental values) further supported the notion of low-level abiotic label absorption. Therefore, the label present in the sediment after sonication/washing could be used to evaluate the proportion of bacteria resistant to dislodgment. (5) All of the described trends were identical between the 2 isotopes used. This added some certainty to the suggested data interpretation.

The above findings indicate that sonication dislodged bacteria from the sediment particles without destroying or altering them. Some bacteria resisted the treatment and remained particle bound. However, there were fewer and fewer of those attached bacteria as the sonication treatment approached its optimal length (80 to $160 \mathrm{~s}$ with specified above instrumentation). The percent of bacteria that remained in the sediment after optimal sonication varied between $1.3 \pm 1.2$ and $14.5 \pm 4.3$ (thymidine measurements) and between $1.9 \pm 1.5$ and $12.1 \pm 5.3$ (leucine data). The above proportions were rather low, thus, the efficacy of the dislodgment was high. Since the other steps in the bacterial enumeration protocol, such as fluorescent staining, filtration, observation, counting, etc., were not likely to significantly contribute to the overall inaccuracy and/ 
or cell losses, the efficacy of dislodgment was a measure of the overall efficacy of direct bacterial enumeration. The latter varied from 88 to $99 \%$ (thymidinebased estimate) and from 88 to $98 \%$ (leucine-based estimate), which supports the $\mathrm{H}_{0}$. Hence, the employed protocol for sediment bacterial enumeration could be considered quantitative. Since this protocol was 1.7 to 5 times more effective than alternative techniques (Epstein \& Rossel 1995), sediment bacteria, at least in sandy sediments, have probably been repeatedly undercounted in earlier studies.

Acknowledgements. This research began as a series of coor dinated individual student research projects, which were part of the 'Microbial Ecology' course taught by the senior author at Boston University Marine Program (BUMP), Marine Biological Laboratory, Woods Hole, MA, USA. Kevin Barry, Peter Behr, Staci Bula, James Cervino, Melissa Diggin, and Francesca Lo helped in conducting some of the experiments The financial aid and logistical support of BUMP is gratefully acknowledged. The junior authors supported part of the research by their tuition. Several tests were performed at the Marine Science Center, Nartheastern University, where the senior author was partly supported by the NSF (Grant OCE9217250). The project would not have been possible without the help of Mr R. Rottenfusser, Zeiss representative at MBL, who kindly made available several Zeiss Axiophot microscopes. The authors would like to thank 4 anonymous reviewers for valuable comments and criticism. This is contribution no. 223 of the Marine Science Center, Northeastern University, Nahant, MA, LSA.

\section{LITERATURE CITED}

Bell RT (1993) Estimating production of heterotrophic bacterioplankton via incorporation of tritiated thymidine. In: Kemp PF, Sherr BF, Sherr EB, Cole JJ (eds) Aquatic microbial ecology. Lewis Publ, Boca Raton, FL, p 495-503

Dale NG (1974) Bacteria in intertidal sediments: factors related to their distribution. Limnol Oceanogr 19:509-518

Dye AH (1983) A method for the quantitative estimation of bacteria from mangrove sedıments. Estuar Coast Shelf Scl $17: 207-212$

Ellery WN, Schleyer MH (1984) Comparison of homogenization and ultrasonication as techniques in extracting attached sedimentary bacterı Mar Ecol Prog Ser 15: $247-250$

This article was submitted to the editor
Epstein SS (1997a) Microblal food webs in marine sediments. I. Trophic interactions and grazing rates in two tidal flat communities. Microb Ecol (in press)

Epstein SS (1997b) Microbial food webs in marine sediments. II. Seasonal changes in trophic interactions in a sandy tidal flat community. Microb Ecol (in press)

Epstein SS, Rossel J (1995) Enumeration of sandy sedıment bacteria: search for optimal protocol. Mar Ecol Prog Ser $117: 289-298$

Findlay RH, Dobbs FC (1993) Quantitative description of microbial communities using lipid analysis. In: Kemp PF, Sherr BF, Sherr EB, Cole JJ (eds) Aquatic microbial ecology. Lewis Publ, Boca Raton, FL, p 271-284

Findlay S (1993) Thymidine incorporation into DNA as an estimate of sediment bacterial production. In: Kemp PF, Sherr BF, Sherr EB, Cole JJ (eds) Aquatic microbial ecology. Lewis Publ, Boca Raton, FL, p 505-508

Kirchman DL (1993) Leucine incorporation as a measure of biomass production by heterotrophic bacteria. In: Kemp PF, Sherr BF, Sherr EB, Cole JJ (eds) Aquatic microbial ecology. Lewis Publ, Boca Raton, FL, p 509-512

Kirchman DL, K'nees E, Hodson RE (1985) Leucine incorporation and its potential as a measure of protein synthesis by bacteria in natural aquatic systems. Appl Environ Micro. biol 49:599-607

Meyer-Reil LA, Dawson R, Liebezeit G, Tiedge H (1978) Fluctuations and interactions of bacterial activity in sandy beach sediments and overlying waters. Mar Biol 48 $161-171$

Sambrook J, Fritsch EF, Maniatis T (1989) Molecular cloning A laboratory manual, Vol 1. Cold Spring Harbor Laboratory Press, Cold Spring Harbor, NY, p 25-28

Schallenberg M, Kalff J, Rasmussen JB (1989) Solutions to problems in enumerating sediment bacteria by direct counts. Appl Environ Microbiol jj:1214-1219

Sokal RR, Rohlf FJ (1987) Introduction to biostatistics, 2nd edn. WH Freeman, San Francisco

Starink M, Krylova IN, Bär-Gilissen MJ, Bak RPM, Cappenberg TE (1994) Rates of benthic protozoan grazing on free and attached sediment bacterra measured with fluorescently stained sediment. Appl Environ Microbiol 60: $2259-2264$

Velji Ml, Albright LJ (1986) Microscopic enumeration of attached marine bacteria of seawater, marine sediment, fecal matter, and kelp blade samples following pyrophosphate and ultrasound treatments. Can J Microbiol 32: 121-126

Velji MI, Albright LJ (1993) Improved sample preparation for enumeration of aggregated aquatic substrate bacteria. In Kemp PF, Sherr BF, Sherr I P, Cole JJ (eds) Aquatic microbial ecology. Lewis Publ, Boca Raton, FL, p 139-142

Manuscript first received: December 5,1990

Revised version accepted: March 5, 1997 